NASA/TM-2002-212007

AIAA-2003-0944

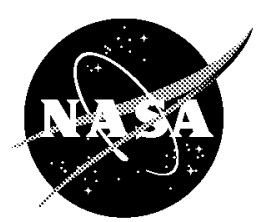

NASA Microgravity Science Competition for High-School-Aged Student Teams

Richard DeLombard and Dennis Stocker

Glenn Research Center, Cleveland, Ohio

Carol Hodanbosi

National Center for Microgravity Research, Cleveland, Ohio

Eric Baumann

Glenn Research Center, Cleveland, Ohio 
The NASA STI Program Office ... in Profile

Since its founding, NASA has been dedicated to the advancement of aeronautics and space science. The NASA Scientific and Technical Information (STI) Program Office plays a key part in helping NASA maintain this important role.

The NASA STI Program Office is operated by Langley Research Center, the Lead Center for NASA's scientific and technical information. The NASA STI Program Office provides access to the NASA STI Database, the largest collection of aeronautical and space science STI in the world. The Program Office is also NASA's institutional mechanism for disseminating the results of its research and development activities. These results are published by NASA in the NASA STI Report Series, which includes the following report types:

- TECHNICAL PUBLICATION. Reports of completed research or a major significant phase of research that present the results of NASA programs and include extensive data or theoretical analysis. Includes compilations of significant scientific and technical data and information deemed to be of continuing reference value. NASA's counterpart of peerreviewed formal professional papers but has less stringent limitations on manuscript length and extent of graphic presentations.

- TECHNICAL MEMORANDUM. Scientific and technical findings that are preliminary or of specialized interest, e.g., quick release reports, working papers, and bibliographies that contain minimal annotation. Does not contain extensive analysis.

- CONTRACTOR REPORT. Scientific and technical findings by NASA-sponsored contractors and grantees.
- CONFERENCE PUBLICATION. Collected papers from scientific and technical conferences, symposia, seminars, or other meetings sponsored or cosponsored by NASA.

- SPECIAL PUBLICATION. Scientific, technical, or historical information from NASA programs, projects, and missions, often concerned with subjects having substantial public interest.

- TECHNICAL TRANSLATION. Englishlanguage translations of foreign scientific and technical material pertinent to NASA's mission.

Specialized services that complement the STI Program Office's diverse offerings include creating custom thesauri, building customized databases, organizing and publishing research results ... even providing videos.

For more information about the NASA STI Program Office, see the following:

- Access the NASA STI Program Home Page at http://www.sti.nasa.gov

- E-mail your question via the Internet to help@sti.nasa.gov

- Fax your question to the NASA Access Help Desk at 301-621-0134

- Telephone the NASA Access Help Desk at 301-621-0390

- Write to: NASA Access Help Desk NASA Center for AeroSpace Information 7121 Standard Drive Hanover, MD 21076 
NASA/TM-2002-212007

AIAA-2003-0944

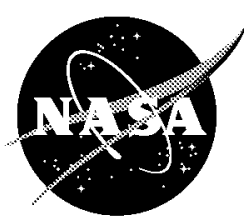

NASA Microgravity Science Competition for High-School-Aged Student Teams

Richard DeLombard and Dennis Stocker

Glenn Research Center, Cleveland, Ohio

Carol Hodanbosi

National Center for Microgravity Research, Cleveland, Ohio

Eric Baumann

Glenn Research Center, Cleveland, Ohio

Prepared for the

41st Aerospace Sciences Meeting and Exhibit

sponsored by the American Institute of Aeronautics and Astronautics

Reno, Nevada, January 6-9, 2003

National Aeronautics and

Space Administration

Glenn Research Center 
Available from

NASA Center for Aerospace Information 7121 Standard Drive

Hanover, MD 21076
National Technical Information Service 5285 Port Royal Road Springfield, VA 22100

Available electronically at http://gltrs.grc.nasa.gov 


\title{
NASA MICROGRAVITY SCIENCE COMPETITION FOR HIGH-SCHOOL-AGED STUDENT TEAMS
}

\author{
Richard DeLombard and Dennis Stocker \\ National Aeronautics and Space Administration \\ Glenn Research Center \\ Cleveland, Ohio \\ Carol Hodanbosi \\ National Center for Microgravity Research \\ Cleveland, Ohio \\ Eric Baumann \\ National Aeronautics and Space Administration \\ Glenn Research Center \\ Cleveland, Ohio
}

\begin{abstract}
NASA participates in a wide variety of educational activities including competitive events. There are competitive events sponsored by NASA and student teams which are mentored by NASA centers. This participation by NASA in public forums serves to bring the excitement of aerospace science to students and educators. A new competition for high-school-aged student teams involving projects in microgravity has completed two pilot years and has national eligibility for teams during the 2002-2003 school year. A team participating in the Dropping In a Microgravity Environment (DIME) will research the field of microgravity science, develop a hypothesis, and prepare a proposal for an experiment to be conducted in a microgravity drop tower facility. A team of NASA scientists and engineers will select the top proposals and those teams will then design and build their experiment apparatus. When the experiment apparatus are completed, team representatives will visit NASA Glenn Research Center in Cleveland, Ohio to conduct their experiment in the 2.2 Second Drop Tower and participate in workshops and center tours.

Presented in this paper is a description of DIME, an overview of the planning and execution of such a program, results from the first two pilot years, and a status of the first national competition.
\end{abstract}

\section{ACRONYMS \& ABBREVIATIONS}

$1 \mathrm{~g} \quad$ Earth's gravitation attraction at sea-level, approximately $9.8 \mathrm{~m} / \mathrm{s}^{2}$ $\begin{array}{ll}\text { DIME } & \text { Dropping In a Microgravity Environment } \\ \text { ISS } & \text { International Space Station } \\ \text { NASA } & \text { National Aeronautics and Space Administration } \\ \text { NCMR } & \text { National Center for Microgravity Research in } \\ & \text { Fluids and Combustion } \\ \text { NSTA } & \text { National Science Teachers Association } \\ \text { ITEA } & \text { International Technology Education Association }\end{array}$

\section{INTRODUCTION}

The NASA Administrator, Sean O'Keefe, stated in congressional testimony that NASA has made education a core mission of the Agency. (ref. 1)

Young people are full of wonder and discovery and NASA has a responsibility to help those traits mature. As we seek to improve our life here, and extend life beyond our known universe, we must work to inspire our children to explore the great frontiers of our solar system and conquer the challenges of propulsion, human biology and technology that keep us close to our home planet. That means we have to help our students understand how mathematics, science, engineering and technology come together to make exploration and innovation possible. Too many students avoid these subjects because they are seen as unpopular, not relevant to their daily lives, or too difficult. These very subject areas though are the fundamental baseline of NASA mission success.

The NASA John H. Glenn Research Center at Lewis Field has long been committed to educational outreach. 
A new educational activity was started in the school year 2000/01 that takes teams of students through a research process similar to processes used by NASA, academia, and commercial researchers. The Dropping In a Microgravity Environment (DIME) program involves student teams from the development of an experiment concept through building the experiment apparatus and conducting the experiment to obtain data which is analyzed and presented in a final report.

At NASA Glenn, the Microgravity Science Division utilizes two drop facilities, the 2.2 Second Drop Tower and the Zero-G Research Facility. Drop towers create microgravity conditions for experiments by allowing the experiments to free fall.

The Microgravity Science Division works jointly with the National Center for Microgravity Research in Fluids and Combustion (NCMR) located on-site at NASA Glenn. NCMR also manages the division's education outreach efforts and plays a major role in the DIME program.

\section{BACKGROUND}

The 2.2 Second Drop Tower, figure 1, operates on 45minute intervals in which a complete drop operation is accomplished. This provides twelve drop slots each day. Typically, experiments are prepared in an off-line laboratory and the 45 minutes available for a drop operation are used efficiently to conduct final experiment preparations, integration to the drop tower, the drop itself, and recovery of the experiment apparatus. The free-fall time in this facility is 2.2 seconds for the 24 meter drop (fig. 2).

The facility has utilized a general-purpose drop rig for many years to drop demonstration science "experiments" for visitors. The demonstration experiments include basic physics demonstration such as sedimentation, balance of forces, and thermal convection. These demonstration devices are described in an educators handbook for a small demonstration drop tower (ref. 2). The general purpose drop rig was modified for use with DIME by creating a standard interface at which student experiment apparatus would be mounted.

Thus, the DIME program was created to allow highschool-age student teams to develop science experiments and then design and build the experiment apparatus to conduct their experiment in a NASA scientific research facility.

\section{DIME COMPETITION FUNDAMENTALS}

As described in the DIME program announcement (ref. 3), DIME allows the student teams to:

- develop an understanding of microgravity science through research,

- develop a hypothesis for some phenomena influenced by gravity, and

- write a scientific proposal for an experiment to test the hypothesis.

The scientific proposals are combined with other requisite forms into a DIME entry package which is submitted to NASA for evaluation against proposals from other teams.

The submitted entries are evaluated by a team of NASA and NCMR scientists and engineers according to the rubric published in the DIME competition announcement. Teams representing the top four proposals are selected as winners. The selected teams then proceed to:

- design their experiment,

- submit the design to NASA for review,

- test the experiment concept,

- improve the design according to tests,

- fabricate the experiment apparatus according to the design (fig. 3),

- develop procedures for the experiment operations,

- conduct their experiment in the NASA 2.2 Second Drop Tower (figs. 4 \& 5),

- modify the experiment apparatus, and/or procedures as required based on testing results, and

- write a final report on the results of their experiment.

These activities support education standards for scientific research.

\section{DIME SCHEDULE}

The DIME program has been designed to be a schoolyear activity as shown in figure 6 . The student teams learn about microgravity, prepare a hypothesis, and write a proposal prior to the submission date in early November. The team may begin this process at their discretion, potentially at the beginning of the school year, during the preceding summer or even during the previous school year. The only critical date in this stage is the postmark date for submission of the proposal to NASA.

The details of the DIME program are available on the internet from a DIME web page (ref. 4) and from a DIME CD-ROM. Both of these sources also provide 
microgravity resources and a description of the 2.2 Second Drop Tower.

A team of NASA and NCMR scientists and engineers evaluate the submitted proposals and announce the selected teams by mid-December. This allows the team to start their experiment design as soon as possible.

A NASA or NCMR mentor is assigned to each team after the selection process has been completed. This scientist or engineer will assist with advice and encouragement for the team during the design and construction phase. The mentor also serves as the team's advocate with the drop tower facility staff during DIME Drop Days. The mentor works directly with the team during DIME Drop Days to ensure successful operation of the experiment.

The selected teams have several due dates in the next several months where they submit a preliminary design package and a final design package for NASA review and approval. The design reviews allow NASA to offer guidance and advice to make the experiment more successful. These reviews also provide insight into the experiment designs to spot potential safety issues early.

Travel and per diem expenses for three days are provided by NASA for four student representatives and an adult advisor from each team to attend the DIME Drop Days at NASA Glenn in Cleveland, Ohio where they will conduct their experiment in the drop tower, participate in workshops, tour the NASA center, and participate in other fun activities.

After DIME Drop Days, each student team prepares a final report summarizing their scientific findings and conclusions as well as summarizing their DIME experience.

\section{EDUCATION STANDARDS}

The DIME program supports specific national standards in science and technology. Participation in DIME will contribute to student mastery of the standards in Table 1.

The students will accomplish a scientific inquiry process by investigating microgravity, developing a hypothesis and conceiving an experiment to test that hypothesis. The experiment apparatus design will need to be developed and built to rigorous safety and operational standards of the NASA facility.

\section{TEAM APPROACH}

A team approach is encouraged where team members with the requisite skills are included. There are a variety of tasks to be accomplished if a team expects to be successful. Science students study the phenomena of microgravity as a topic of physics and they research experiment concepts as topics of physical science. Skills in page layout and word processing are necessary due to the specific rules for preparing a proposal, including page layout format, number of pages, and technical content. Attention to detail is important in the final preparation of an entry to verify the proposal and associated forms meet the DIME rules. Technology students prepare the conceptual drawings in the proposal as well as the design drawings once the team is selected. The construction of the experiment apparatus can be done by or with technology students. Science students conduct $1 \mathrm{~g}$ ground tests with the experiment to prove out operations and to gather a baseline experiment operation with which to compare the microgravity results.

Mentors are an important part of a team's work in DIME, including the adult team advisor and local scientists and engineers. The adult team advisor and a local mentor (if there is one) should guide the students, not do the work for the students.

\section{SELECTION PROCESS}

A selection process for evaluating and selecting the winning teams from the submitted proposals has been developed. The DIME rules state that the proposals are created in a 'blind' fashion in which no information about students' names or location is included. This permits a fair evaluation of all proposals based on scientific merit with no bias for location or ethnicity of students, organization, or advisor.

Emphasis is placed on the science and engineering aspects of the proposal as seen in the breakdown of points in Table 2. A subsection of the rubric used for DIME during the $2002 / 03$ school year is included as Table 3. The entire rubric is included in the DIME Program Announcement to guide the teams while preparing their proposal. The evaluators also use this rubric to evenly score the proposals. The possible scores by section are included in the announcement.

\section{SELECTION OF WINNERS}

The results of the evaluation are presented to the DIME staff for the formal selection of winners. After selection, the advisor for each selected team is notified of their success. The team is soon rewarded with the 
shipment of a metal plate on which their experiment apparatus will be constructed.

At that time also, the advisor of each non-selected team is given regrets from the DIME staff as well as a summary of the evaluation results of their proposal. A participation certificate and NASA educational material are sent to each team.

\section{ALTERNATIVES FOR NON-SELECTED TEAMS}

For non-selected teams, the efforts put forth in microgravity study and scientific research to create a proposal may be used as fundamentals for science fair projects. With the team selection announcement in midDecember, there is sufficient time for students to expand their work into projects for spring science fairs. These teams may also use the opportunity to critically examine their proposal, their hypothesis, and the experiment concept. The remaining school year time may be spent honing the proposal as a DIME proposal entry the following year.

If the sponsoring organization (e.g. high school or museum) has a small drop tower, the team could design and build a smaller demonstration device for that drop tower. If a small drop tower is not available, perhaps the team can channel their interest into building one (ref. 2).

\section{DESIGN AND FABRICATION OF EXPERIMENT APPARATUS}

Following their selection, a NASA or NCMR mentor is assigned to guide the team through the more difficult stage of design, fabrication, and testing.

NASA furnishes each selected team a base plate and electrical connectors (as required) which together form the interface with the NASA rig used in the drop tower. The teams begin to develop the design of their experiment in more detail and submit a preliminary design to NASA for review. This review is to assess the technical aspects of the experiment design for:

- proper interface with the NASA rig,

- adherence to safety requirements,

- acceptable operation in the drop tower, and

- to make sure each team is progressing (and not waiting for the last minute)

One month later, the teams submit their final design primarily for review of compliance with the safety requirements. When construction is completed, the experiment is shipped to NASA Glenn in a NASAprovided shipping container. A safety committee inspects the experiment apparatus and its design package before it will be operated in the drop tower. Safety is a high priority in the drop tower and student experiments are naturally expected to meet the applicable safety standards, as are all other experiments.

\section{DIME DROP DAYS AT NASA GLENN}

NASA provides travel expenses for four students and an adult advisor to attend DIME Drop Days at NASA Glenn in Cleveland, Ohio. The primary objective is to operate the teams' experiments in the 2.2 Second Drop Tower while also participating in workshops and touring some of the major Center facilities. One of the first activities after 'breaking the ice' is to tour the drop tower facility, witness the drop operations of an experiment, and check over their experiment apparatus since it was shipped to NASA.

The workshops feature problem solving and team building exercises for the students, both in their original teams and as 'mixed' teams. Training in NASAdeveloped image analysis software is also provided to assist the teams in interpreting their experiment data, if required. The NASA or NCMR mentor also works with the team to operate the experiment, assist with procedures and data interpretation. Visits to NASA microgravity research laboratories are also provided to the DIME teams to see first-hand some of the research currently being conducted.

\section{OPERATION OF STUDENT EXPERIMENTS IN DROP TOWER}

The students are involved in each step of the operation of their experiment apparatus. After a short orientation to the Education Rig, which carries their experiment in the drop tower, the students install their experiment in the rig, adjust the camera and load their sample materials. The team's operational procedures are checked and tested in $1 \mathrm{~g}$ for proper sequence and timing with the experiment apparatus and the rig. The electronic data logger (if used) is programmed and its operation and data are tested.

The student team's apparatus is finally tested in a microgravity environment on their first drop operation test. The initial test may yield valid data and also evaluates whether the procedures are correct, the settings are adjusted properly, and the experiment apparatus performs as expected. Problems found at this time can be corrected before the drops on the following day. Difficulties experienced in the initial drops in the first two years of Drop Days have included premature ignition of a combustion sample (procedure problem) 
and a low electromagnet magnetic field strength (hardware problem). These initial tests take the students and their experiment apparatus through the sequence of steps involved in preparing and operating their experiment through the complete drop operation.

The teams' experiment operations in the drop tower are webcast over the internet for interested people to observe. The web address for the webcast is included on the DIME web page. (ref. 4)

\section{STUDENT EXPERIMENTS FOR FIRST TWO PILOT YEARS}

The initial year for DIME occurred during the $2000 /$ 01 school year with two teams participating. One experiment studied the progression of a flame across a cotton cloth sample in microgravity as a study in space station fire safety for crew members. The other experiment studied the effect of microgravity on the gravity-driven motion of soybeans in a carbonated beverage, where bubbles nucleating on the soybeans lift them in normal gravity, then burst at the surface allowing the beans to sink.

The second pilot year for DIME was the following school year with four teams participating. There was one combustion experiment and three fluid physics experiments. The combustion experiment studied the flame spread across standard office paper in microgravity. The first fluid physics experiment studied the interface shape between different combinations of oils and water in a microgravity environment. The second fluid physics experiment studied the effect of microgravity on the shape of a magnetic fluid immersed in alcohol within a magnetic field. The third fluid physics experiment studied the effect of microgravity and gravity on the shape and motion of immiscible fluid droplets.

\section{SUMMARY}

The student team members and the advisors enjoyed the DIME program and felt that they experienced a process similar to NASA research. The DIME teams participated in a process of creating a hypothesis, developing an experiment to test that hypothesis, and creating a proposal to accomplish that research. As opposed to standard high school laboratory experiments, in DIME the students had to design and build their experiment apparatus and procedures for conducting the tests.

Performing the tests in the NASA 2.2 Second Drop Tower and analyzing the data with NASA mentors was a high point of their research. The DIME teams concluded their DIME research with a final report.

\section{REFERENCES}

1) Statement of Sean O'Keefe, Administrator, National Aeronautics and Space Administration before the Subcommittee on Science, Technology, and Space Committee on Commerce, Science, and Transportation, United States Senate, June 19, 2002

2) NASA (1998), The Microgravity Demonstrator, EG1998-12-49-MSFC, NASA Marshall Space Flight Center, Huntsville, AL

3) DIME Program Announcement, NASA Glenn Research Center,

http: //microgravity.grc.nasa.gov/ MSD /DIME /DIME 2003_PA.pdf

4) DIME web page, http: //microgravity. grc . nasa.gov/ DIME . html 
Table 1: National education standards which apply to DIME

\begin{tabular}{|c|}
\hline $\begin{array}{l}\text { National Science Teachers Association } \\
\text { (NSTA) Standards }\end{array}$ \\
\hline Science as inquiry \\
\hline + Abilities necessary to do scientific inquiry \\
\hline Science and technology \\
\hline + Abilities of technological design \\
\hline $\begin{array}{l}\text { International Technology Education } \\
\text { Association (ITEA) Standards }\end{array}$ \\
\hline Design \\
\hline + Students will develop an understanding of the \\
attributes of design
\end{tabular}

Table 2: Possible points for major sections of DIME proposals

\begin{tabular}{|l|c|}
\hline \multicolumn{1}{|c|}{ Section } & Points \\
\hline \hline I. Science Objectives & 41 \\
\hline II. Technical Plan & 30 \\
\hline III. Team Organization & 9 \\
\hline $\begin{array}{l}\text { IV. Creativity, Originality, } \\
\text { Attention To Detail }\end{array}$ & 12 \\
\hline V. Resource Credits & 8 \\
\hline Total & 100 \\
\hline
\end{tabular}


Table 3: One subsection of the DIME rubric for proposal evaluation

\section{SCIENCE OBJECTIVES}

(A) RESEARCH QUESTION / HYPOTHESIS

\begin{tabular}{|c|c|c|c|c|}
\hline POINTS & $\begin{array}{l}\text { 1. Does the proposal } \\
\text { have a clear research } \\
\text { question and } \\
\text { hypothesis? }\end{array}$ & $\begin{array}{l}\text { 2. Does the proposal } \\
\text { have a hypothesis } \\
\text { related to the } \\
\text { research question? }\end{array}$ & $\begin{array}{l}\text { 3. Is microgravity a } \\
\text { major factor in this } \\
\text { proposed } \\
\text { experiment? }\end{array}$ & $\begin{array}{l}\text { 4. Is the hypothesis } \\
\text { testable in } 2.2 \\
\text { seconds? }\end{array}$ \\
\hline 1 & $\begin{array}{l}\text { Neither research question } \\
\text { nor hypothesis are } \\
\text { presented in the proposal. }\end{array}$ & $\begin{array}{l}\text { The relationship of the } \\
\text { hypothesis and the } \\
\text { research question cannot } \\
\text { be determined. }\end{array}$ & $\begin{array}{l}\text { No clear connection to } \\
\text { microgravity is } \\
\text { explained. }\end{array}$ & $\begin{array}{l}\text { Unable to detect factors } \\
\text { in experiment to } \\
\text { determine response time. }\end{array}$ \\
\hline 2 & $\begin{array}{l}\text { An unclear research } \\
\text { question or hypothesis is } \\
\text { stated. }\end{array}$ & $\begin{array}{l}\text { The hypothesis is } \\
\text { unclear; the experiment } \\
\text { relates poorly or not at all } \\
\text { to the research question. }\end{array}$ & $\begin{array}{l}\text { The need for } \\
\text { microgravity effect is } \\
\text { unclear or was not } \\
\text { explained clearly. }\end{array}$ & $\begin{array}{l}\text { The information is } \\
\text { unclear or not stated; the } \\
\text { experiment samples may } \\
\text { need to be modified. }\end{array}$ \\
\hline 3 & $\begin{array}{l}\text { A research question and } \\
\text { hypothesis are present } \\
\text { but both are poorly } \\
\text { stated, or may contain } \\
\text { inaccuracies. }\end{array}$ & $\begin{array}{l}\text { The hypothesis is clear } \\
\text { and is somewhat related } \\
\text { to the research question. }\end{array}$ & $\begin{array}{l}\text { A microgravity effect is } \\
\text { clear and somewhat } \\
\text { utilized in the } \\
\text { experiment. }\end{array}$ & $\begin{array}{l}\text { Response time short } \\
\text { enough for reaction to be } \\
\text { complete within } 2.2 \\
\text { seconds. }\end{array}$ \\
\hline 4 & $\begin{array}{l}\text { A clear research question } \\
\text { and hypothesis are } \\
\text { present but they are not } \\
\text { testable, variables are not } \\
\text { identified, or they contain } \\
\text { inaccuracies. }\end{array}$ & $\begin{array}{l}\text { The hypothesis is clearly } \\
\text { stated and it appears that } \\
\text { the experiment will yield } \\
\text { significant data related to } \\
\text { the research question. }\end{array}$ & $\begin{array}{l}\text { The microgravity effect } \\
\text { is clearly stated and is } \\
\text { utilized in the } \\
\text { experiment. }\end{array}$ & $\begin{array}{l}\text { N/A } \\
\text { (item } 4 \text { is only } \\
\text { worth } 3 \text { points) }\end{array}$ \\
\hline 5 & $\begin{array}{l}\text { The research question is } \\
\text { clear, the hypothesis is } \\
\text { testable, variables are } \\
\text { identified; variables are } \\
\text { identified as dependent, } \\
\text { independent, and control } \\
\text { is defined. }\end{array}$ & $\begin{array}{l}\text { The hypothesis is clearly } \\
\text { stated and the experiment } \\
\text { will yield data that } \\
\text { address research question } \\
\text { and hypothesis in a } \\
\text { compelling way. }\end{array}$ & $\begin{array}{l}\text { Microgravity is essential } \\
\text { to the hypothesis and the } \\
\text { research question and is } \\
\text { described in detail. }\end{array}$ & $\mathrm{N} / \mathrm{A}$ \\
\hline
\end{tabular}




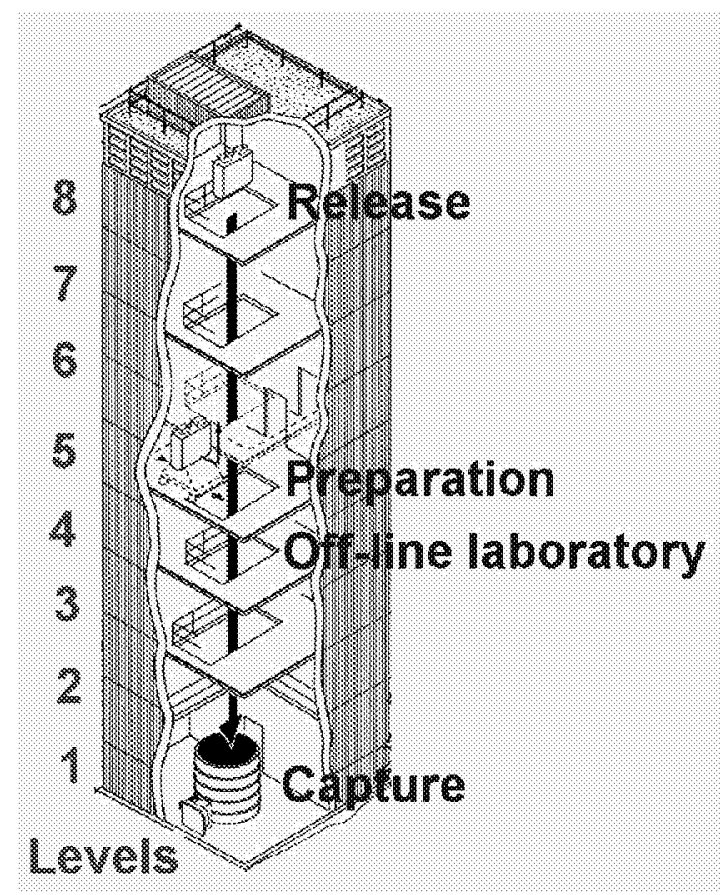

Figure 1: Diagram of the 2.2 Second Drop Tower.

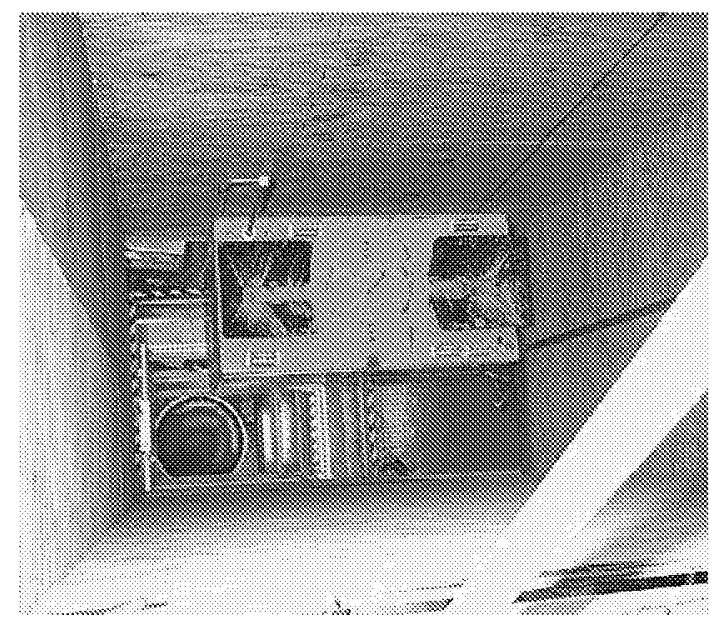

Figure 2: Drag shield and experiment (inside) midway through the 2.2 second free-fall.

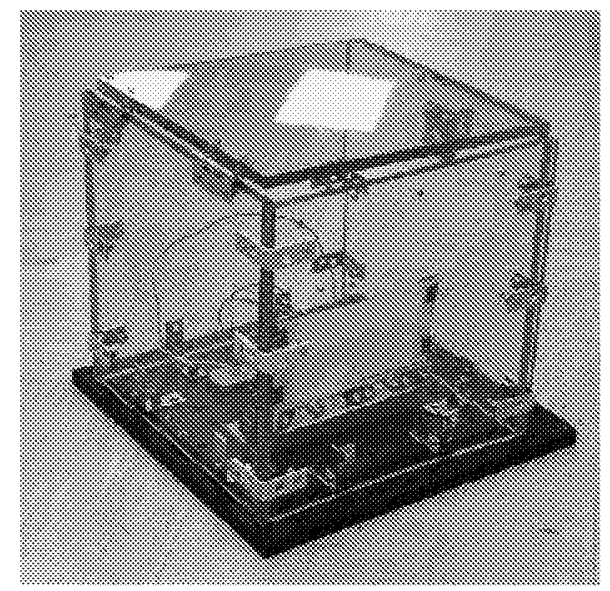

Figure 3: Combustion chamber apparatus built by a student team for the DIME competition. The student's equipment is mounted to the NASA-provided base plate.

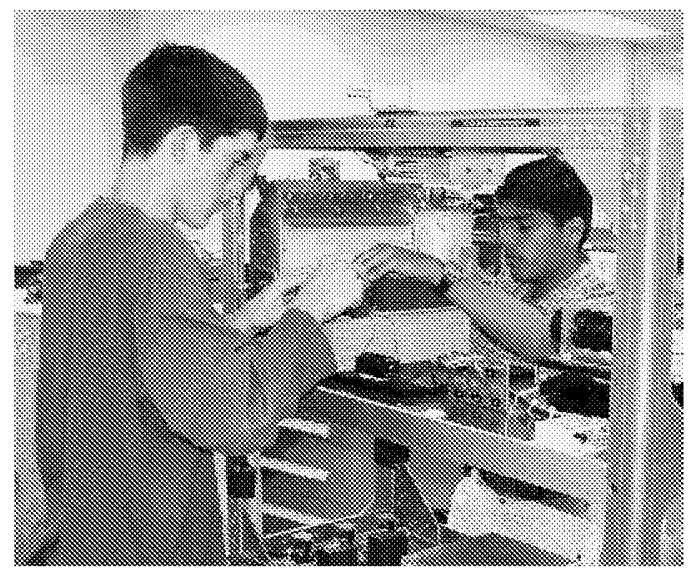

Figure 4: Student team members load samples into their experiment apparatus which has been mounted into the NASA drop rig. 


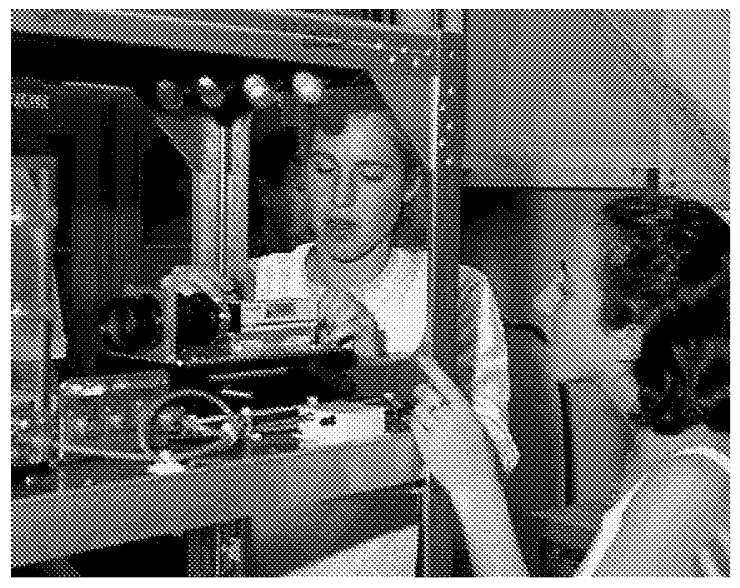

Figure 5: Student team members adjust the video camera on the NASA drop rig.

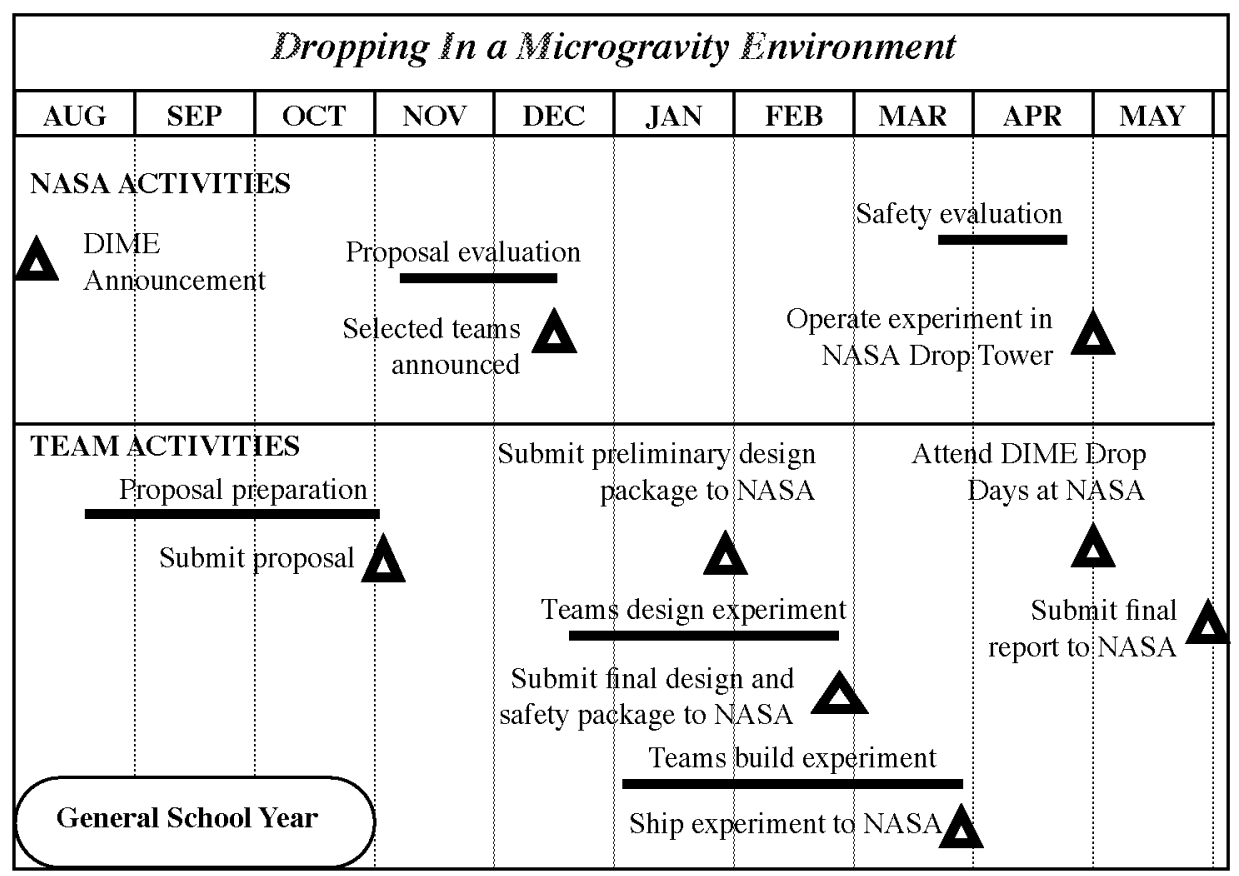

Figure 6: DIME school year schedule 

Davis Highway, Suite 1204, Arlington, VA 22202-4302, and to the Office of Management and Budget, Paperwork Reduction Project (0704-0188), Washington, DC 20503.

\section{\begin{tabular}{l|l|l} 
1. AGENCY USE ONLY (Leave blank) & 2. REPORT DATE & 3. REPORT TYPE AND DATES COVERED
\end{tabular}}

\begin{tabular}{|l|r|r|} 
Technical Memorandum \\
\hline
\end{tabular}

\begin{tabular}{l|l|l|}
\hline 4. TITLE AND SUBTITLE & 5. FUNDING NUMBERS
\end{tabular}

NASA Microgravity Science Competition for High-School-Aged Student Teams

6. AUTHOR(S)

WBS-22-101-58-13

Richard DeLombard, Dennis Stocker, Carol Hodanbosi, and Eric Baumann

7. PERFORMING ORGANIZATION NAME(S) AND ADDRESS(ES)

National Aeronautics and Space Administration

John H. Glenn Research Center at Lewis Field

Cleveland, Ohio 44135-3191

9. SPONSORING/MONITORING AGENCY NAME(S) AND ADDRESS(ES)

10. SPONSORING/MONITORING

AGENCY REPORT NUMBER

National Aeronautics and Space Administration

Washington, DC 20546-0001

NASA TM-2002-212007

AIAA-2003-0944

\section{SUPPLEMENTARY NOTES}

Prepared for the 41st Aerospace Sciences Meeting and Exhibit sponsored by the American Institute of Aeronautics and Astronautics, Reno, Nevada, January 6-9, 2003. Richard DeLombard, Dennis Stocker, and Eric Baumann, NASA Glenn Research Center; Carol Hodanbosi, National Center for Microgravity Research, Cleveland, Ohio 44135.

Responsible person, Richard DeLombard, organization code 6727, 216-433-5285.

12a. DISTRIBUTION/AVAILABILITY STATEMENT

Unclassified - Unlimited

Subject Category: 80 12b. DISTRIBUTION CODE

Available electronically at http://gltrs.grc.nasa.gov

Distribution: Nonstandard

This publication is available from the NASA Center for AeroSpace Information, 301-621-0390.

13. ABSTRACT (Maximum 200 words)

NASA participates in a wide variety of educational activities including competitive events. There are competitive events sponsored by NASA and student teams which are mentored by NASA centers. This participation by NASA in public forums serves to bring the excitement of aerospace science to students and educators. A new competition for highschool-aged student teams involving projects in microgravity has completed two pilot years and will have national eligibility for teams during the 2002-2003 school year. A team participating in the Dropping In a Microgravity Environment will research the field of microgravity, develop a hypothesis, and prepare a proposal for an experiment to be conducted in a microgravity drop tower facility. A team of NASA scientists and engineers will select the top proposals and those teams will then design and build their experiment apparatus. When the experiment apparatus are completed, team representatives will visit NASA Glenn in Cleveland, Ohio for operation of their facility and participate in workshops and center tours. Presented in this paper will be a description of DIME, an overview of the planning and execution of such a program, results from the first two pilot years, and a status of the first national competition.

\section{SUBJECT TERMS}

Research and development; Education; Competition; Drop towers; Microgravity; Schools; Students

\begin{tabular}{|c|c|}
\hline $\begin{array}{c}\text { 17. SECURITY CLASSIFICATION } \\
\text { OF REPORT }\end{array}$ & $\begin{array}{c}\text { 18. SECURITY CLASSIFICATION } \\
\text { OF THIS PAGE } \\
\text { Unclassified }\end{array}$ \\
Unclassified
\end{tabular}

NSN 7540-01-280-5500

\section{NUMBER OF PAGES}

15

16. PRICE CODE

19. SECURITY CLASSIFICATION
OF ABSTRACT
Unclassified

\section{ICATION} Unclassified 